Neurodegener Dis 2016;16:12-21

DOI: $10.1159 / 000440840$
Received: June 2, 2015

Accepted after revision: September 3, 2015 Published online: November 10, 2015

\title{
Genetic Disorders with Tau Pathology: A Review of the Literature and Report of Two Patients with Tauopathy and Positive Family Histories
}

\author{
Pawel Tacik $^{a}$ Monica Sanchez-Contreras ${ }^{b}$ Rosa Rademakers ${ }^{b}$ \\ Dennis W. Dickson ${ }^{b}$ Zbigniew K. Wszolek ${ }^{a}$ \\ Departments of ${ }^{\mathrm{a}}$ Neurology and ${ }^{\mathrm{b}}$ Neuroscience, Mayo Clinic Florida, Jacksonville, Fla., USA
}

\section{Key Words}

Tauopathies · Genetics · Tau pathology ·

Microtubule-associated protein tau gene

\begin{abstract}
Background: Tauopathies are a group of neurodegenerative disorders characterized by the pathological accumulation of hyperphosphorylated and insoluble tau protein within neurons and glia. Although most cases are sporadic, hereditary tauopathies have also been reported. Summary: In this article, we review genetic disorders in which tau pathology has been reported and present two novel families with primary tauopathies. Mutations in the microtubule-associated protein tau gene (MAPT) cause a small subset of primary tauopathies. Mutations in 21 other genes and an 18q deletion syndrome have also been reported to be associated with tau pathology reminiscent of Alzheimer's disease, corticobasal degeneration, progressive supranuclear palsy, argyrophilic grain disease or Pick's disease. In 8 of the 21 genes, tau pathology was only seen in cases with some 'specific' mutations. In the remaining genes, tau pathology, often in the form of Alzheimer-type neurofibrillary lesions, was a common finding but was 'not mutation specific'. The probands of the two families were diagnosed with progressive
\end{abstract}

supranuclear palsy based on clinicopathological evaluation. Their family histories were relevant for parkinsonism in 3 siblings of family 1 and 1 brother and the father from family 2 , but these were not autopsy-confirmed. DNA from the brains of the probands from these families was screened for MAPT and leucine-rich repeat kinase 2 gene mutations, but no mutations were identified. Key Messages: MAPT mutations are a cause of familial tauopathies, but other genes have also been associated with tau pathology. Novel genes still await discovery.

c) 2015 S. Karger AG, Basel

\section{Introduction}

Tauopathies are a group of neurodegenerative disorders with pathological accumulation of hyperphosphorylated and insoluble tau protein within neurons and glia [1]. In primary tauopathies tau inclusions are the major neuropathological abnormality, whereas in secondary tauopathies tau pathology occurs in association with other more specific pathology [2].

\section{P.T. and M.S.-C. contributed equally to this work.}

\section{KARGER}

E-Mail karger@karger.com

www.karger.com/ndd
(C) 2015 S. Karger AG, Basel

1660-2854/15/0162-0012\$39.50/0
Prof. Zbigniew K. Wszolek

Department of Neurology, Mayo Clinic Florida

4500 San Pablo Road South

Jacksonville, FL 32224 (USA)

E-Mail Wszolek.Zbigniew@ mayo.edu 
The tau protein promotes tubulin polymerization and stabilizes microtubules. Tau is encoded by the microtubule-associated protein tau gene (MAPT) on chromosome 17 [3]. Of 14 MAPT exons, exons 2, 3 and 10 undergo alternative splicing, and therefore, the mature tau proteins vary in size from 352 to 441 amino acids. Alternative splicing of exon 10 leads to two functionally different isoforms that contain either three or four 31 -amino acid repeats depending on whether exon 10 is included (4R tau) or not (3R tau) [3]. Exon 10 encodes 1 of 4 tau microtubule-binding repeat regions; the remaining 3 are encoded by exons 9,11 and 12. In normal adult human brains, the level of $3 \mathrm{R}$ isoforms is approximately equal to that of $4 \mathrm{R}$ isoforms [4]. Morphological and biochemical heterogeneity of the primary tauopathies is associated with the predominance of tau isoforms. This and the proportion of tau deposits within neurons or glial cells, together with the areas of the brain affected influence the clinical phenotype. The classical phenotypes of primary tauopathies correspond with the modern classification of frontotemporal lobar degeneration (FTLD) [5] and thus the term FTLD-tau can be applied [4]. These phenotypes include progressive supranuclear palsy (PSP), corticobasal degeneration (CBD), Pick's disease (PiD), globular glial tauopathies (GGTs), argyrophilic grain disease (AGD), primary agerelated tauopathy (PART), chronic traumatic encephalopathy (CTE), and frontotemporal dementia (FTD) with parkinsonism linked to chromosome 17 (FTDP17) $[4,6,7]$.

Based on the predominance of $3 \mathrm{R} / 4 \mathrm{R}$ isoforms, tauopathies can be grouped into 4R tauopathies, including PSP, CBD, AGD, GGT and some forms of FTDP-17, while 3R tauopathies include PiD and some forms of FTDP-17 [4, 7]. In PART, CTE, and some other forms of FTDP-17, there is a mixture of $3 \mathrm{R}$ and $4 \mathrm{R}$ tau pathology [7]. Neuronal lesions predominate in $3 \mathrm{R}$ tauopathies, while $4 \mathrm{R}$ tau accumulates in both neurons and glial cells $[4,7]$. Tau pathology can also differ depending on the conformational state of tau in neuronal Alzheimer-type paired helical filaments or Pick-type straight filaments [6].

The overwhelming majority of tauopathies occur sporadically, but tauopathies linked to $M A P T$ mutations (i.e. FTDP-17) frequently share pathological and biochemical features with sporadic tauopathies $[6,8]$. Additionally, tau pathology has been reported in mutations in other genes. We review the genetics of tauopathies and describe two previously unpublished families with primary tauopathies.

\section{Methods}

We searched the PubMed database for all papers published in English that contained the words 'familial' or 'hereditary' and 'tauopathies', 'progressive supranuclear palsy', 'corticobasal degeneration', 'Pick's disease', 'globular glial tauopathies', 'argyrophilic grain disease' and 'tauopathy-associated disorders'.

Genealogical, clinical and laboratory investigations were performed by means of medical chart review and telephone interviews with members of the two families. The probands of each family were neuropathologically diagnosed with tauopathy by an experienced neuropathologist (D.W.D.). DNA from the brains of the probands, which were stored in the Mayo Clinic Florida brain bank, was screened for mutations in all MAPT exons expressed in human brains (0-5, 7, 9-13) and LRRK2 exons 31 and 41, and flanking intronic regions using the Sanger sequencing method. The clinical study protocols were approved by the Mayo Clinic Institutional Review Board, and the autopsies were performed after approval by the next of kin or an individual with legal power of attorney.

\section{Results and Discussion}

\section{Literature Review}

More than 50 MAPT mutations have been reported in about 150 families with primary tauopathies (see http:// www.molgen.ua.ac.be/ADMutations) [6], whereas the overwhelming majority of tauopathies occurs sporadically. This is also true for PSP, the most common primary tauopathy, which has an estimated prevalence of 5-6/ 100,000. Of all MAPT mutations, 10 have been associated with the phenotype of PSP, and 9 of these 10 mutations affected exon 10, increasing the expression of $4 \mathrm{R}$ tau isoforms [10].

Apart from MAPT mutations, deletion of part of the long arm of chromosome 18 as well as mutations in 21 other genes have been reported to occur with tau pathology. The tau pathology in these cases was reminiscent of that seen in Alzheimer's disease (AD), CBD, PSP, AGD or PiD and was often accompanied by deposition of other proteins, including $\alpha$-synuclein, $\beta$ amyloid or TDP-43 (table 1). Tau protein has been reported to interact with some of these proteins, but the nature and type of these interactions are still a matter of debate. Results from some cellular research and animal models suggest that hyperphosphorylated tau protein is causally related with the activation of $\beta$-amyloidinduced microtubule disassembly and cell death. Other authors proposed alternative ways of interaction and suggested either the causative role of $\beta$-amyloid in tau pathology or synergistic toxic effects of both proteins [11]. $\beta$-Amyloid-induced oxidative stress is considered 
Table 1. Genetic disorders with tau pathology (except for tauopathies linked to MAPT mutations)

\begin{tabular}{|c|c|c|c|c|c|c|}
\hline Gene & $\begin{array}{l}\text { Cytogenetic } \\
\text { location }\end{array}$ & Disorders & Inheritance & $\begin{array}{l}\text { Primary molecular } \\
\text { pathology (CNS) }\end{array}$ & $\begin{array}{l}\text { Tau pathology findings (seen with } \\
\text { multiple mutations unless specified) }\end{array}$ & $\begin{array}{l}\text { Ref. } \\
\text { No. }\end{array}$ \\
\hline TARDBP & $1 \mathrm{p} 36.22$ & $\begin{array}{l}\text { ALS with or } \\
\text { without FTD }\end{array}$ & $\begin{array}{l}\text { Autosomal } \\
\text { dominant }\end{array}$ & $\begin{array}{l}\text { Ubiquitylated } \\
\text { TDP-43 deposits }\end{array}$ & $\begin{array}{l}\text { p.I383V: NFT, pretangles, neuropil } \\
\text { threads, } 4 \text { R positive rings in granular } \\
\text { neurons of dentate gyrus, bush-like, } \\
\text { tufted and thorn-shaped astrocytes in } \\
\text { the amygdala }\end{array}$ & 7,26 \\
\hline PSEN2 & $1 q 42.13$ & Familial AD4 & $\begin{array}{l}\text { Autosomal } \\
\text { dominant }\end{array}$ & $\begin{array}{l}\text { Deposits of } A \beta \\
\text { (and also tau) }\end{array}$ & $\mathrm{AD}$ & 14 \\
\hline CYP27A1 & $2 q 35$ & $\begin{array}{l}\text { Cerebrotendinous } \\
\text { xanthomatosis }\end{array}$ & $\begin{array}{l}\text { Autosomal } \\
\text { recessive }\end{array}$ & $\begin{array}{l}\text { Cholestanol and } \\
\text { cholesterol deposits }\end{array}$ & $\begin{array}{l}\text { p.R127W (c.379C>T): AGD-like, } \\
\text { predominantly } 4 \mathrm{R}, \text { Braak stage III }\end{array}$ & 7,24 \\
\hline$C N B P$ & $3 q 21$ & $\begin{array}{l}\text { DM2 (PROMM, } \\
\text { Ricker syndrome) }\end{array}$ & $\begin{array}{l}\text { Autosomal } \\
\text { dominant }\end{array}$ & $\begin{array}{l}\text { Deposits of RNA } \\
\text { nuclear inclusions } \\
\text { (foci) }\end{array}$ & AD-like (NFTs, Braak stage III-IV) & 27 \\
\hline SNCA & $4 \mathrm{q} 22.1$ & PD/PARK1 & $\begin{array}{l}\text { Autosomal } \\
\text { dominant }\end{array}$ & $\begin{array}{l}\text { a-Synuclein } \\
\text { deposits }\end{array}$ & $\begin{array}{l}\text { p.G51D, p.A53T, p.A30P, SNCA } \\
\text { duplication in heterozygous and } \\
\text { homozygous state: AD-like with 3R } \\
\text { and } 4 \text { R NFTs (Braak stage } 0 \text {-IV), } \\
\text { pre-tangles, neuropil threads }\end{array}$ & 28 \\
\hline SLC17A5 & $6 q 13$ & $\begin{array}{l}\text { Sialic acid storage } \\
\text { disease }\end{array}$ & $\begin{array}{l}\text { Autosomal } \\
\text { recessive }\end{array}$ & $\begin{array}{l}\text { Storage of free } \\
\text { sialic acid }\end{array}$ & AD-like (NFTs) & 29 \\
\hline PRKN & $6 q 26$ & PD/PARK2 & $\begin{array}{l}\text { Autosomal } \\
\text { recessive }\end{array}$ & $\begin{array}{l}\text { a-Synuclein } \\
\text { deposits } \\
\text { (infrequently) }\end{array}$ & $\begin{array}{l}\text { p.C212Y: PSP-like with globose-type } \\
\text { NFTs and «tufted astrocytes`, no Lewy } \\
\text { bodies; exon } 3 \text { deletion and p.K } 211 \mathrm{~N} \text { : } \\
\text { tau-positive thorn-shaped astrocytes, } \\
\text { tau-positive astrocytes, no NFTs, no } \\
\text { a-synuclein, no Lewy bodies }\end{array}$ & 21,30 \\
\hline
\end{tabular}

\begin{tabular}{|c|c|c|c|c|c|c|}
\hline C9ORF72 & $9 \mathrm{p} 21.2$ & ALS and/or FTD & $\begin{array}{l}\text { Autosomal } \\
\text { dominant }\end{array}$ & $\begin{array}{l}\text { Deposits of } \\
\text { dipeptide repeat, } \\
\text { RNA nuclear } \\
\text { inclusions (foci), } \\
\text { sometimes TDP-43 }\end{array}$ & $\begin{array}{l}\text { AD-like with NFTs (Braak stage } \\
\text { II-III); C9ORF72 and MAPT p.A239T } \\
\text { variant: 3R PBli }\end{array}$ & 25,31 \\
\hline$L R R K 2$ & $12 \mathrm{q} 12$ & PD/PARK8 & $\begin{array}{l}\text { Autosomal } \\
\text { dominant }\end{array}$ & $\begin{array}{l}\text { a-Synuclein } \\
\text { deposits }\end{array}$ & $\begin{array}{l}\text { p.G2019S: PSP-like, predominantly 4R } \\
\text { (no } \alpha \text {-synuclein); p.R1441C: PSP-like } \\
\text { predominantly 4R (no } \alpha \text {-synuclein) }\end{array}$ & 18,19 \\
\hline ITM2B & $13 q 14.3$ & $\begin{array}{l}\text { Hereditary } \\
\text { cerebral amyloid } \\
\text { angiopathy } \\
\text { (familial British } \\
\text { dementia and } \\
\text { familial Danish } \\
\text { dementia) }\end{array}$ & $\begin{array}{l}\text { Autosomal } \\
\text { dominant }\end{array}$ & $\mathrm{A} \beta$ deposits & $\begin{array}{l}\text { AD-like with amyloid-Bri or amyloid- } \\
\text { Dan deposition with tau-positive NFTs } \\
\text { (Braak stage V-VI), neuropil threads } \\
\text { and dystrophic neurites }\end{array}$ & 7,32 \\
\hline PSEN1 & $14 \mathrm{q} 24.2$ & Familial AD3 & $\begin{array}{l}\text { Autosomal } \\
\text { dominant }\end{array}$ & $\begin{array}{l}\text { Deposits of } A \beta \\
\text { (and also tau) }\end{array}$ & $\begin{array}{l}\text { AD; in addition } 3 \text { mutations with } \\
\text { FTD phenotype: p.G183V (PBli, no } \\
\text { extracellular A } \beta \text { ), p.M146L (PBli, A } \beta \text {, } \\
\text { NFTs), p.M146V (PBli, A } \beta, \text { NFTs) }\end{array}$ & $14-17$ \\
\hline NPC2 & $14 \mathrm{q} 24.3$ & \multirow{2}{*}{$\begin{array}{l}\text { Niemann-Pick } \\
\text { disease, type C }\end{array}$} & \multirow{2}{*}{$\begin{array}{l}\text { Autosomal } \\
\text { recessive }\end{array}$} & \multirow{2}{*}{$\begin{array}{l}\text { Accumulation of } \\
\text { cholesterol }\end{array}$} & \multirow{2}{*}{ AD-like (NFTs) } & \multirow{2}{*}{7,29} \\
\hline NPC1 & $18 q 11.2$ & & & & & \\
\hline
\end{tabular}


Table 1 (continued)

\begin{tabular}{|c|c|c|c|c|c|c|}
\hline Gene & $\begin{array}{l}\text { Cytogenetic } \\
\text { location }\end{array}$ & Disorders & Inheritance & $\begin{array}{l}\text { Primary molecular } \\
\text { pathology (CNS) }\end{array}$ & $\begin{array}{l}\text { Tau pathology findings (seen with } \\
\text { multiple mutations unless specified) }\end{array}$ & $\begin{array}{l}\text { Ref. } \\
\text { No. }\end{array}$ \\
\hline CLN6 & $15 q 23$ & Kufs disease & $\begin{array}{l}\text { Autosomal } \\
\text { recessive }\end{array}$ & $\begin{array}{l}\text { Accumulation of } \\
\text { lipopigments }\end{array}$ & AD-like (NFTs) & 29 \\
\hline \multirow[t]{2}{*}{$G R N$} & $17 q 21.32$ & $\begin{array}{l}\text { FTLD with } \\
\text { ubiquitin-positive } \\
\text { inclusions }\end{array}$ & $\begin{array}{l}\text { Autosomal } \\
\text { dominant }\end{array}$ & $\begin{array}{l}\text { Ubiquitylated } \\
\text { TDP-43 deposits }\end{array}$ & $\begin{array}{l}\text { IVS709-2A4G (c.709-2A4G): AD-like } \\
\text { (NFTs, Braak stage 0-II) }\end{array}$ & 33 \\
\hline & $18 q 11-21$ & $\begin{array}{l}\text { 18q deletion } \\
\text { syndrome (De } \\
\text { Grouchy } \\
\text { syndrome 2) }\end{array}$ & $\begin{array}{l}\text { Few inherited } \\
\text { cases reported } \\
\text { (from carriers } \\
\text { of chromosomal } \\
\text { rearrangement) }\end{array}$ & Not given & AD-like (NFTs) & 29 \\
\hline$D M P K$ & $19 q 13.3$ & $\begin{array}{l}\text { DM1 } \\
\text { (Curschmann- } \\
\text { Steinert myotonic } \\
\text { dystrophy) }\end{array}$ & $\begin{array}{l}\text { Autosomal } \\
\text { dominant }\end{array}$ & $\begin{array}{l}\text { Deposits of RNA } \\
\text { nuclear inclusions } \\
\text { (foci) }\end{array}$ & AD-like (NFTs, Braak stage III-IV) & 27 \\
\hline PRNP & $20 \mathrm{p} 13$ & $\begin{array}{l}\text { Familial prion } \\
\text { diseases (fCJD, } \\
\text { GSS, FFI) }\end{array}$ & $\begin{array}{l}\text { Autosomal } \\
\text { dominant }\end{array}$ & $\begin{array}{l}\text { Prion protein } \\
\text { deposits }\end{array}$ & $\begin{array}{l}\text { AD-like (NFTs are not uncommon in } \\
P R N P \text { mutations, may reach Braak } \\
\text { stage VI in p.Q160X and p.Y } 145 \mathrm{X} \\
\text { mutations, especially in cases of long } \\
\text { disease duration) }\end{array}$ & 7,34 \\
\hline PANK2 & $20 \mathrm{p} 13$ & $\begin{array}{l}\text { Neuro- } \\
\text { degeneration } \\
\text { with brain iron } \\
\text { accumulation }\end{array}$ & $\begin{array}{l}\text { Autosomal } \\
\text { recessive }\end{array}$ & Iron deposition & $\begin{array}{l}\text { AD-like with NFTs (in } 1 \text { case Braak } \\
\text { stage V), neuropil threads, tau-positive } \\
\text { glia; presence of } \alpha \text {-synuclein }\end{array}$ & 35 \\
\hline$A P P$ & $21 \mathrm{q} 21.3$ & Familial AD1 & $\begin{array}{l}\text { Autosomal } \\
\text { dominant }\end{array}$ & $\begin{array}{l}\text { Deposits of } A \beta \\
\text { (and also tau) }\end{array}$ & $\mathrm{AD}$ & 14 \\
\hline
\end{tabular}

Genetic disorders with tau pathology (except for tauopathies linked to MAPT mutations). A $\beta=\beta$-Amyloid peptide; AD = Alzheimer's disease; $\mathrm{AD} 4$ = Alzheimer's disease type 4; $\mathrm{AGD}=$ argyrophilic grain disease; ALS = amyotrophic lateral sclerosis; $A P P=$ amyloid precursor protein gene; ATP6AP2 = ATPase, $\mathrm{H}+$ transporting, lysosomal accessory protein 2 gene; C9ORF72= chromosome 9 open reading frame 72 gene; $\mathrm{CBD}=$ corticobasal degeneration; $C N B P=\mathrm{CCHC}$-type zinc finger, nucleic acid binding protein gene; $\mathrm{CNS}=$ central nervous system; CYP27A1 = cytochrome P450, family 27, subfamily A, polypeptide 1 gene; DM1 = myotonic dystrophy type 1 ; DM2 $(\mathrm{PROMM})=$ myotonic dystrophy type 2 (proximal myotonic myopathy); DMPK = dystrophia myotonica protein kinase gene; fCJD = familial Creutzfeldt-Jacob disease; FFI = fatal familial insomnia; FTLD = frontotemporal lobar degeneration; FTD = frontotemporal dementia; $G R N$ = progranulin gene; GSS = Gerstmann-Sträussler-Scheinker syndrome; ITM2B = integral membrane protein 2B gene; $L R R K 2$ = leucine-rich repeat kinase 2 gene; NFTs = neurofibrillary tangles; NPC1 = Niemann-Pick disease, type C1, gene; NPC2 = Niemann-Pick disease, type C2, gene; PANK2 = pantothenate kinase 2 gene; PARK1 = autosomal dominant Parkinson's disease 1; PARK2 = juvenile, autosomal recessive Parkinson's disease type 2; PARK8 = autosomal dominant Parkinson's disease 8; PD = Parkinson's disease; $\mathrm{PBli}=$ Pick body-like inclusions; $P R K N=$ parkin gene; $P R N P=$ prion protein gene; $P S E N 1=$ presenilin-1 gene; PSP = progressive supranuclear palsy; SLC9A6 = solute carrier family 9, subfamily A (NHE6, cation proton antiporter 6), member 6 gene; SLC17A5 = solute carrier family 17 (acidic sugar transporter), member 5 gene; SNCA = a-synuclein gene; SQSTM1 = sequestosome 1; TARDBP $=$ transactivationresponse DNA binding protein gene; TRPM7 = transient receptor potential cation channel, subfamily $\mathrm{M}$, member 7 gene; XPDS = X-linked parkinsonism with spasticity; 3R = 3-repeat tau isoform; 4R = 4-repeat tau isoform. 
to be essential for tau hyperphosphorylation and subsequent neurofibrillary tangle (NFT) formation [12]. According to the tau axis hypothesis, progressively increasing concentrations of hyperphosphorylated tau in dendrites make neurons vulnerable to lesions caused by $\beta$-amyloid at the postsynaptic compartment. However, the process of tau hyperphosphorylation is driven by $\beta$-amyloid $[11,12]$. Tau has also been reported to interact with $\alpha$-synuclein. Both proteins share some similarities. They are heat-stable, unfolded, contain characteristic repeats, and tau can also be present in Lewy bodies. Recent reports have shown that a-synuclein stimulates kinase-mediated phosphorylation of tau initiated by oxidative stress [12]. Prion proteins can also interact with tau by binding directly to tubulin and inhibiting tubulin oligomerization and, as a consequence, microtubule assembly [13].

In 8 of the 21 genes, tau pathology was detected in patients only with some 'specific' mutations. In the remaining 12 genes (PSEN2, CNBP, SLC17A5, C9ORF72, ITM2B, NPC2, NPC1, CLN6, DMPK, PRNP, PANK2, $A P P)$, tau pathology in the form of Alzheimer-type NFTs was a common finding (table 1). Therefore we attributed this tauopathy to a nonspecific result of these mutations. Mutations of one gene, presenilin-1 (PSEN1), comprise both 'specific' and 'nonspecific' mutations with two different tauopathy phenotypes: AD and FTD. In the majority of the cases, it remains unclear what impact the primary mutation has on aggregation of tau protein and whether tau pathology is directly linked to these mutations or only an incidental finding.

In familial $\mathrm{AD}$ due to mutations in amyloid precursor protein (APP), PSEN1 or presenilin-2 (PSEN2) genes, accumulation of $\beta$-amyloid in senile plaques and amyloid angiopathy are considered to be the primary defects, but accumulation of hyperphosphorylated tau in NFTs, neuropil threads and dystrophic neurites in senile plaques is clearly involved in disease pathogenesis, and it is strongly linked to clinical phenotype [14]. Three PSEN1 mutations (p.M146L, p.M146V and p.G183V) have been reported to present with a clinical phenotype of FTD. At autopsy, the carriers of these mutations had neuronal inclusions reminiscent of Pick bodies [15-17]. Of note, the case with the p.G183V mutation showed only tau pathology but no extracellular amyloid deposits [15].

PSP-like pathology with substantia nigra globose NFTs and tufted astrocytes in the basal ganglia, but no significant neuronal loss in the subthalamic nucleus, was reported in the p.G2019S mutation in the leucine-rich repeat kinase 2 gene (LRRK2). Contrary to other $L R R K 2$ mutation cases, there was no evidence of abnormal accumulation of $a$-synuclein, but only tau pathology in these particular patients with p.G2019S or p.R1441C mutations in LRRK2 (table 1) [18, 19]. Another LRRK2 mutation, p.R1441H, was reported in a patient with Parkinson's disease (PD) whose clinical manifestation evolved to PSP. However, the neuropathology was not reported [20].

The clinicopathological phenotype reminiscent of PSP was also reported in a patient with parkinsonism and vertical gaze palsy due to a p.C212Y mutation in the parkin (PRKN) gene. On autopsy, globose-type NFTs and tufted astrocytes were described but no Lewy bodies were identified. Although PRKN mutations have been associated with autosomal recessive, juvenile-onset $\mathrm{PD}$, it is not unusual for there to be a lack of Lewy bodies or a-synuclein staining in cases with $P R K N$ mutations [21]. PSP was also seen in four members of a Spanish family, and one of these cases was autopsy confirmed. Genetic testing did not show any MAPT mutations, but PSP was linked to $3.4 \mathrm{cM}$ locus on chromosome 1q31.1 [9].

Tau pathology that resembled CBD was reported in patients with c.1012_1020del mutation of the solute carrier family 9, subfamily A (NHE6, cation proton antiporter 6), member 6 gene (SLC9A6). This included a variable degree of cortical and basal ganglia atrophy, coiled bodies and astrocytic plaques; however, severe degeneration of Purkinje cells and dentate nucleus and an absence of ballooned neurons differed from the classical CBD phenotype in these patients [22].

In a patient with a p.S115S mutation in the ATPase $\mathrm{H}+$ transporting lysosomal accessory protein 2 gene (ATP6AP2), there were plaque-like structures in the striatum consisting of tau-positive glial processes similar to astrocytic plaques [23]. The latter are frequently seen in $\mathrm{CBD}$, but in this patient they were limited in distribution, while more widespread in cortical and basal ganglia in CBD.

In patients with cerebrotendinous xanthomatosis caused by the p.R127W mutation in the cytochrome P450, family 27, subfamily A, polypeptide 1 gene (CYP27A1), tau pathology took the form of grains, tangles and coiled bodies that were predominantly found in the limbic system [24]. This phenotype is similar to that observed in sporadic AGD of the elderly.

Coexistence of the p.A239T variant of the MAPT gene and hexanucleotide expansions in C9ORF72 in a patient led to a clinicopathological phenotype of FTD without symptoms of motor neuron disease and with neuronal inclusions that were reminiscent of Pick bodies. The
16

Neurodegener Dis 2016;16:12-21 DOI: $10.1159 / 000440840$
Tacik/Sanchez-Contreras/Rademakers/ Dickson/Wszolek 
Table 2. Clinical, genealogical and neuropathological data of two probands

\begin{tabular}{|c|c|c|}
\hline & Proband 1 (family 1 ) & Proband 2 (family 2 ) \\
\hline Sex & $\mathrm{F}$ & M \\
\hline Handedness & Right & Right \\
\hline Age at death, years & 79 & 69 \\
\hline Disease duration, years & 4 & 9 \\
\hline First symptom & Eye movement impairment & $\begin{array}{l}\text { Behavioral changes (disinhibition, agitation, } \\
\text { violent outbursts, high libido), parkinsonism }\end{array}$ \\
\hline FTD type & PPA & $\begin{array}{l}\text { bvFTD, later PPA (impairment of verbal fluency, } \\
\text { motor speed and processing speed) }\end{array}$ \\
\hline Motor neuron disease sign & Spasticity & No \\
\hline Parkinsonism & Axial rigidity, backward falls & $\begin{array}{l}\text { Gait imbalance, postural instability, shuffling feet, } \\
\text { backward falls, axial rigidity }\end{array}$ \\
\hline Gaze palsy & Vertical & Vertical \\
\hline Other signs and symptoms & $\begin{array}{l}\text { Retrocollis, dysarthria, dysphagia, alteration of } \\
\text { language and cognition, anxiety, nocturia }\end{array}$ & $\begin{array}{l}\text { Mild cognitive impairment, hypophonia, urine } \\
\text { incontinence, erectile dysfunction }\end{array}$ \\
\hline Brain imaging & $\begin{array}{l}\text { CT (at } 75 \text { years): no vascular lesions, marked } \\
\text { to moderate atrophy of brain, especially } \\
\text { cerebellum, prominent ventricles }\end{array}$ & $\begin{array}{l}{ }^{18} \mathrm{~F}-\mathrm{FDG} \text { PET/CT (at } 65 \text { years): bilateral } \\
\text { asymmetric left }>\text { right decreased FDG activity } \\
\text { involving the anteromedial portions of the } \\
\text { bilateral temporal lobes. No significant cortical } \\
\text { atrophy } \\
\text { MRI (at } 68 \text { years): prominent cerebral sulci and } \\
\text { ventricles consistent with volume loss, chronic } \\
\text { periventricular microvascular ischemic changes }\end{array}$ \\
\hline $\begin{array}{l}\text { Family history of movement } \\
\text { disorders and dementia }\end{array}$ & $\begin{array}{l}1 \text { brother and } 2 \text { sisters with parkinsonism late } \\
\text { in life; no autopsy }\end{array}$ & $\begin{array}{l}1 \text { brother with PSP, father parkinsonism; no } \\
\text { autopsy }\end{array}$ \\
\hline MAPT mutation & No & No \\
\hline Brain weight, $g$ & 1,080 & 1,280 \\
\hline Cortical atrophy & $\begin{array}{l}\text { Moderate atrophy (parasagittal superior } \\
\text { frontal and superior parietal convexity) }\end{array}$ & No \\
\hline NFT Braak stage & III & II-III \\
\hline Globus pallidus (gliosis) & Mild & Mild \\
\hline STN NL & Severe & Severe \\
\hline $\begin{array}{l}\text { SN pig. } \\
\text { SN NL }\end{array}$ & $\begin{array}{l}\text { Decreased } \\
\text { Marked }\end{array}$ & $\begin{array}{l}\text { Decreased } \\
\text { Marked }\end{array}$ \\
\hline MTR cortex NL & Mild to moderate & Moderate \\
\hline Other features & $\begin{array}{l}\text { Mild atrophy of callosum, enlargement of } \\
\text { lateral ventricle }\end{array}$ & $\begin{array}{l}\text { Atrophy of dentate nucleus, superior cerebellar } \\
\text { peduncle (severe) and midbrain, enlargement of } \\
\text { fourth ventricle }\end{array}$ \\
\hline Clinical-pathological diagnosis & PSP & PSP \\
\hline
\end{tabular}

bvFTD = Behavioral variant of frontotemporal dementia; CT = computer tomography; $\mathrm{F}=$ female; $18 \mathrm{~F}-\mathrm{FDG}$ PET/CT = fluorine-18 fluorodeoxyglucose positron emission tomography/computer tomography; $\mathrm{M}=$ male; MTR cortex $\mathrm{NL}=$ neuronal loss in the motor cortex; NFTs = neurofibrillary tangles; PPA = primary progressive aphasia; $\mathrm{PSP}=$ progressive supranuclear palsy; $\mathrm{SN}$ NL $=$ neuronal loss of the substantia nigra; SN pig. = pigmentation of the substantia nigra; STN NL = subthalamic nucleus neuronal loss. 
Fig. 1. Pedigrees of family 1 (a) and family 2 (b). Round symbols indicate women; squares indicate men; figures inside symbols indicate number of children; diagonal lines indicate that the individual is deceased. The arrow indicates the proband. A caret indicates an autopsy was completed. Black symbols indicate individual with PSP; black and white symbols indicate individuals with parkinsonism.

Fig. 2. Semiquantitative assessment of tau pathology in two probands. The pattern of neuronal and glial tau pathology is similar in the probands. Number and shading represent lesion density score: $0=$ none; $1=$ sparse; 2 = moderate; 3 = frequent.

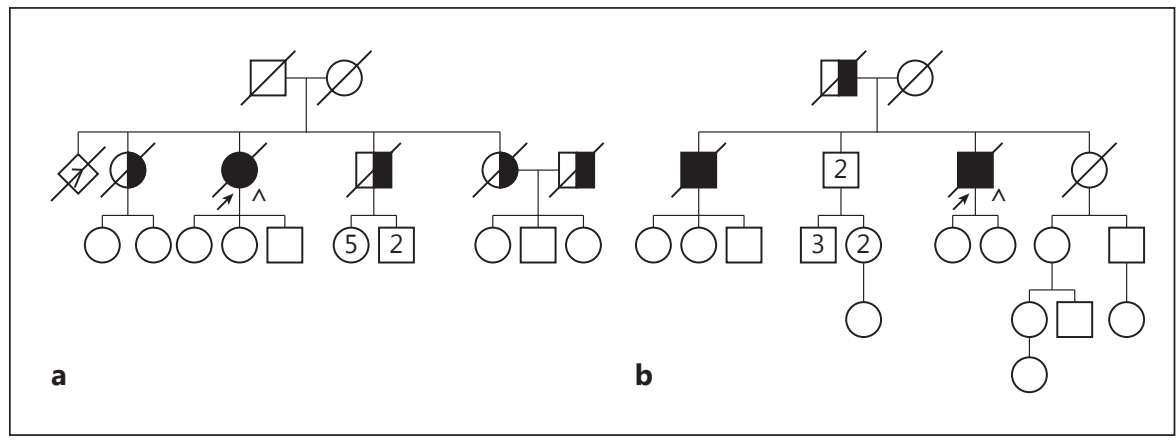

\begin{tabular}{|c|c|c|c|c|c|c|c|c|}
\hline \multirow{2}{*}{$\begin{array}{c}\text { Region } \\
\text { Proband: }\end{array}$} & \multicolumn{2}{|c|}{$\begin{array}{c}\text { NFT \& } \\
\text { pre-NFT }\end{array}$} & \multicolumn{2}{|c|}{$\begin{array}{l}\text { Coiled } \\
\text { bodies }\end{array}$} & \multicolumn{2}{|c|}{$\begin{array}{c}\text { Tufted } \\
\text { astrocytes }\end{array}$} & \multicolumn{2}{|c|}{$\begin{array}{l}\text { Tau(+) } \\
\text { threads }\end{array}$} \\
\hline & 1 & 2 & 1 & 2 & 1 & 2 & 1 & 2 \\
\hline Temporal cortex & 2 & 1 & 1 & 0 & 2 & 0 & 1 & 0 \\
\hline Superior frontal & 3 & 2 & 3 & 1 & 3 & 2 & 2 & 1 \\
\hline Motor cortex & 3 & 2 & 3 & 3 & 3 & 2 & 3 & 3 \\
\hline Striatum & 2 & 1 & 2 & 3 & 3 & 3 & 2 & 1 \\
\hline Globus pallidus & 3 & 2 & 2 & 3 & 1 & 0 & 3 & 2 \\
\hline Basal nucleus & 2 & 3 & 1 & 2 & 0 & 1 & 2 & 3 \\
\hline Hypothalamus & 3 & 3 & 1 & 1 & 1 & 0 & 2 & 2 \\
\hline Thalamus & 3 & 3 & 3 & 3 & 2 & 3 & 3 & 3 \\
\hline $\begin{array}{l}\text { Subthalamic } \\
\text { nucleus }\end{array}$ & 3 & 3 & 2 & 3 & 3 & 3 & 3 & 3 \\
\hline Red nucleus & 3 & 3 & 3 & 3 & 2 & 2 & 3 & 3 \\
\hline Substantia nigra & 3 & 3 & 2 & 2 & 1 & 2 & 3 & 2 \\
\hline Midbrain tectum & 2 & 3 & 3 & 3 & 2 & 3 & 3 & 3 \\
\hline Locus ceruleus & 3 & 3 & 1 & 1 & 0 & 0 & 3 & 3 \\
\hline $\begin{array}{l}\text { Pontine } \\
\text { tegmentum }\end{array}$ & 3 & 3 & 2 & 3 & 0 & 0 & 3 & 3 \\
\hline Pontine base & 3 & 3 & 2 & 2 & 0 & 0 & 2 & 3 \\
\hline $\begin{array}{l}\text { Medullary } \\
\text { tegmentum }\end{array}$ & 3 & 3 & 2 & 3 & 0 & 0 & 3 & 3 \\
\hline Inferior olive & 2 & 3 & 2 & 2 & 1 & 0 & 2 & 3 \\
\hline Dentate nucleus & 3 & 2 & 1 & 2 & 0 & 1 & 2 & 1 \\
\hline $\begin{array}{l}\text { Cerebellar white } \\
\text { matter }\end{array}$ & 0 & 0 & 3 & 3 & 0 & 0 & 2 & 3 \\
\hline
\end{tabular}

proband's 2 brothers were carriers of only the C9ORF72 mutation and developed amyotrophic lateral sclerosis, but not FTD [25].

\section{Clinicopathological, Genealogical and Genetic}

Analysis of Two Families with Tauopathy

Family 1

The proband was a 79-year-old, right-handed woman with a 4-year history of a motor and cognitive disorder that initially presented with eye movement impairment. Later, she developed speech difficulties that were suggestive of progressive aphasia. She had backward falls, memory problems and episodes of anxiety. Two years before her death, neurological evaluation showed vertical gaze palsy, dysarthria and dysphagia. Motor signs included axial rigidity, retrocollis and limb spasticity. Brain computer tomography scans revealed moderate-to-marked atrophy of the brain, especially of the cerebellum, with
18

Neurodegener Dis 2016;16:12-21 DOI: $10.1159 / 000440840$
Tacik/Sanchez-Contreras/Rademakers/ Dickson/Wszolek 
prominent ventricles (table 2). Her family history was remarkable for parkinsonism in a brother and 2 sisters. No postmortem studies were available on other family members (fig. 1a).

The proband's calculated brain weight was $1,080 \mathrm{~g}$. It had moderate cortical atrophy over the parasagittal superior frontal and superior parietal convexities. The subthalamic nucleus was slightly smaller than normal. There was no atrophy of the superior cerebellar peduncle. The substantia nigra had mild decreased pigmentation. Histologically, there was marked neuronal loss in the subthalamic nucleus and the substantia nigra. The motor cortex and the globus pallidus showed mild to moderate neuronal loss and gliosis. The cerebellum revealed patchy Purkinje cell loss and Bergmann gliosis in the vermis. The cerebellar dentate nucleus had focal neuronal loss and gliosis.

Alzheimer-type neurofibrillary pathology assessed with thioflavin S fluorescent microscopy was consistent with Braak NFT stage III (table 2). Neither senile plaques nor Lewy bodies were detected. Tau immunohistochemistry revealed a range of lesions, including pretangles, NFTs, tufted astrocytes, coiled bodies and neuropil threads (fig. 2). There was neither $\alpha$-synuclein nor TDP43 immunostaining present.

The overall pathological findings were those of a tauopathy most consistent with PSP, although cortical tau pathology was greater than usual. Involvement of the frontal cortex and the corticobulbar and corticospinal tracts correlated with clinical findings of dementia, dysphagia and limb spasticity.

\section{Family 2}

The proband was a right-handed man who died at the age of 69 years following a 9-year disease course. His first symptoms were parkinsonism and behavioral changes, including disinhibition, agitation, violent outbursts and increased libido.

Five years after symptom onset, he had difficulty multitasking, as well as visuoperceptual and visuospatial impairments. His language difficulties included reduced verbal fluency and impairments in motor speed and processing speed. The findings were consistent with primary progressive aphasia. Memory problems were also noted. On neurological examination he had axial rigidity, shuffling gait, postural instability with backward falls and hypophonia. He also had vertical gaze palsy, urinary incontinence and erectile dysfunction. ${ }^{18} \mathrm{~F}$-fluorodeoxyglucose positron emission tomography showed decreased activity in anteromedial portions of both temporal lobes, which was worse on the left. There was no significant cortical atrophy.

Eight years after symptomatic onset he was wheelchair-bound and mute. He scored 22/30 on the Montreal Cognitive Assessment scale. There was no response to $75 \mathrm{mg} / 300 \mathrm{mg}$ of carbidopa/levodopa therapy. Magnetic resonance imaging showed minimal periventricular white matter changes that were consistent with chronic microvascular ischemic changes. The cerebral sulci and prominent ventricles indicated volume loss. Molecular genetic analysis of transactivation response DNA binding protein $(T A R D B P)$ gene did not reveal any mutations.

The patient's family history was remarkable for PSP in a brother and parkinsonism in his father (fig. 1b). Neither diagnosis was pathologically confirmed.

The proband's calculated brain weight was $1,280 \mathrm{~g}$. The cerebral hemisphere had a normal configuration, and the sulci and gyri showed no atrophy over the convexity. The periventricular white matter had patchy gray discoloration. The subthalamic nucleus was much smaller than normal. The infratentorial structures showed midbrain atrophy with dilation of the aqueduct, enlargement of the fourth ventricle and severe atrophy of the superior cerebellar peduncle. The substantia nigra had decreased pigmentation. The cerebellar sections showed marked atrophy of the dentate nucleus.

The neocortex had no significant neuronal loss or gliosis, except in the motor cortex where there was subjective neuronal loss. The globus pallidus revealed mild vascular calcification and mild gliosis. The thalamus had gliosis in the ventrolateral region. The subthalamic nucleus showed severe neuronal loss and gliosis, with severe neuronal and glial tau pathology. The thalamic fasciculus and internal capsule had many threads and coiled bodies. The substantia nigra showed marked neuronal loss in the ventrolateral cell group, but less neuronal loss in dorsal and medial cell groups. This was associated with extraneuronal neuromelanin, gliosis and neuronal and glial tau pathology. The cerebellum showed no significant Purkinje cell loss or Bergmann gliosis. The cerebellar dentate nucleus had severe neuronal loss and gliosis with severe grumose degeneration.

The Braak NFT stage was consistent with stage II-III (table 2). No senile plaques were present in the cortex or hippocampus. Tau immunohistochemistry revealed a range of lesions, including pretangles, NFTs, tufted astrocytes, coiled bodies and neuropil threads (fig. 2). There was neither $\alpha$-synuclein nor TDP-43 immunostaining present.

The overall pathological findings were those of a primary tauopathy consistent with PSP, although oligoden- 
droglial pathology was more marked than usual in both the forebrain and hindbrain structures.

Sequence analysis of the entire coding region of the $M A P T$ gene identified no mutation in the probands of family 1 and family 2 . Additional sequencing of LRRK2 exons 31 and 41 in both probands revealed no mutation at codons 1441 and 2019. Both probands were homozygous for the H1 MAPT haplotype.

\section{Conclusions}

MAPT mutations are a cause of familial tauopathies. However, the 18q deletion syndrome and mutations in 21 other genes may present with tau pathology, most frequently in the context of other well-defined pathologies. Importantly, while we aimed to provide a comprehensive overview of familial cases with known gene mutations and tau pathology, it remains unclear whether tau pathology is caused by the reported gene mutations or merely presents an incidental finding.

In our two families, the clinicopathological findings were consistent with primary tauopathies in the form of
PSP. Molecular genetic analysis of all coding regions of $M A P T$ did not bring clarification. Screening of the LRRK2 codons 1441 and 2019 that previously had been linked to the PSP phenotype $[18,19]$ did not reveal any mutations. Despite a positive family history, we conclude that the lack of mutations in MAPT and LRRK2 suggests that unknown genetic factors and possibly mutations in new genes may play a role in the pathogenesis of familial tauopathies.

\section{Acknowledgments}

We thank Kelly E. Viola, ELS, for her editorial support. We would also like to thank Audrey J. Strongosky for her assistance with this project. This study was supported by the NIH P50NS072187 (D.W.D., Z.K.W.), the Max Kade Foundation (P.T.), an Allergan Medical Educational Grant (P.T.), a gift from Carl Edward Bolch Jr. and the Susan Bass Bolch Foundation (Z.K.W.), and Mayo Clinic Neuroscience Focused Research Team (Z.K.W.).

\section{Disclosure Statement}

The authors have no conflicts of interest to declare.

\section{References}

1 Lee VM, Goedert M, Trojanowski JQ: Neurodegenerative tauopathies. Annu Rev Neurosci 2001;24:1121-1159.

$\checkmark 2$ Revesz T, Holton JL: Anatamopathological spectrum of tauopathies. Mov Disord 2003; 18(suppl 6):S13-S20.

3 Neve RL, Harris P, Kosik KS, Kurnit DM, Donlon TA: Identification of cDNA clones for the human microtubule-associated protein tau and chromosomal localization of the genes for tau and microtubule-associated protein 2. Brain Res 1986;387:271-280.

-4 Dickson DW, Kouri N, Murray ME, Josephs KA: Neuropathology of frontotemporal lobar degeneration-tau (FTLD-tau). J Mol Neurosci 2011;45:384-389.

5 Cairns NJ, Bigio EH, Mackenzie IR, Neumann M, Lee VM, Hatanpaa KJ, White CL 3rd, Schneider JA, Grinberg LT, Halliday G, Duyckaerts C, Lowe JS, Holm IE, Tolnay M, Okamoto K, Yokoo H, Murayama S, Woulfe J, Munoz DG, Dickson DW, Ince PG, Trojanowski JQ, Mann DM: Neuropathologic diagnostic and nosologic criteria for frontotemporal lobar degeneration: consensus of the consortium for frontotemporal lobar degeneration. Acta Neuropathol 2007;114:5-22.
6 Ghetti B, Oblak AL, Boeve BF, Johnson KA, Dickerson BC, Goedert M: Invited review: Frontotemporal dementia caused by microtubule-associated protein tau gene (MAPT) mutations: a chameleon for neuropathology and neuroimaging. Neuropathol Appl Neurobiol 2015;41:24-46.

7 Kovacs GG: Invited review: neuropathology of tauopathies: principles and practice. Neuropathol Appl Neurobiol 2015;41:3-23.

-8 Foster NL, Wilhelmsen K, Sima AA, Jones MZ, D'Amato CJ, Gilman S: Frontotemporal dementia and parkinsonism linked to chromosome 17: a consensus conference. Conference participants. Ann Neurol 1997;41:706715.

-9 Ros R, Gómez Garre P, Hirano M, Tai YF, Ampuero I, Vidal L, Rojo A, Fontan A, Vazquez A, Fanjul S, Hernandez J, Cantarero S, Hoenicka J, Jones A, Ahsan RL, Pavese N, Piccini P, Brooks DJ, Perez-Tur J, Nyggard T, de Yébenes JG: Genetic linkage of autosomal dominant progressive supranuclear palsy to 1q31.1. Ann Neurol 2005;57:634-641.

10 Im SY, Kim YE, Kim YJ: Genetics of progressive supranuclear palsy. J Mov Disord 2015;8: 122-129.
11 Ittner LM, Gotz J: Amyloid-beta and tau - a toxic pas de deux in Alzheimer's disease. Nat Rev Neurosci 2011;12:67-72.

12 Mietelska-Porowska A, Wasik U, Goras M, Filipek A, Niewiadomska G: Tau protein modifications and interactions: their role in function and dysfunction. Int J Mol Sci 2014; 15:4671-4713.

13 Nieznanski K, Podlubnaya ZA, Nieznanska H: Prion protein inhibits microtubule assembly by inducing tubulin oligomerization. Biochem Biophys Res Commun 2006;349:391-399.

-14 Shepherd C, McCann H, Halliday GM: Variations in the neuropathology of familial Alzheimer's disease. Acta Neuropathol 2009;118: 37-52.

15 Dermaut B, Kumar-Singh S, Engelborghs $S$, Theuns J, Rademakers R, Peeters K, Claes S, Cruts M, Martin JJ, De Deyn P, Van Broeckboven C: A novel presenilin 1 mutation (Gly183Val) is associated with Pick's disease in the absence of beta-amyloid plaques. Neurobiol Aging 2004;25:S61-S61.

16 Riudavets MA, Bartoloni L, Troncoso JC, Pletnikova O, St George-Hyslop P, Schultz M, Sevlever G, Allegri RF: Familial dementia with frontotemporal features associated with M146V presenilin-1 mutation. Brain Pathol 2013;23:595-600. 
17 Halliday GM, Song YJ, Lepar G, Brooks WS, Kwok JB, Kersaitis C, Gregory G, Shepherd CE, Rahimi F, Schofield PR, Kril JJ: Pick bodies in a family with presenilin-1 Alzheimer's disease. Ann Neurol 2005;57:139-143.

18 Rajput A, Dickson DW, Robinson CA, Ross OA, Dachsel JC, Lincoln SJ, Cobb SA, Rajput ML, Farrer MJ: Parkinsonism, Lrrk2 G2019S, and tau neuropathology. Neurology 2006;67: 1506-1508.

19 Zimprich A, Biskup S, Leitner P, Lichtner P, Farrer M, Lincoln S, Kachergus J, Hulihan M, Uitti RJ, Calne DB, Stoessl AJ, Pfeiffer RF, Patenge N, Carbajal IC, Vieregge P, Asmus F, Muller-Myhsok B, Dickson DW, Meitinger T, Strom TM, Wszolek ZK, Gasser T: Mutations in Lrrk2 cause autosomal-dominant parkinsonism with pleomorphic pathology. Neuron 2004;44:601-607.

20 Spanaki C, Latsoudis H, Plaitakis A: Lrrk2 mutations on Crete: $\mathrm{R} 1441 \mathrm{H}$ associated with PD evolving to PSP. Neurology 2006;67: 1518-1519.

-21 Sanchez MP, Gonzalo I, Avila J, De Yebenes JG: Progressive supranuclear palsy and tau hyperphosphorylation in a patient with a C212Y parkin mutation. J Alzheimers Dis 2002;4:399-404.

-22 Garbern JY, Neumann M, Trojanowski JQ, Lee VM, Feldman G, Norris JW, Friez MJ, Schwartz CE, Stevenson R, Sima AA: A mutation affecting the sodium/proton exchanger, SLC9A6, causes mental retardation with tau deposition. Brain 2010;133:1391-1402.

-23 Korvatska O, Strand NS, Berndt JD, Strovas T, Chen DH, Leverenz JB, Kiianitsa K, Mata IF, Karakoc E, Greenup JL, Bonkowski E, Chuang J, Moon RT, Eichler EE, Nickerson DA, Zabetian CP, Kraemer BC, Bird TD, Raskind WH: Altered splicing of ATP6AP2 causes X-linked parkinsonism with spasticity (XPDS). Hum Mol Genet 2013;22:3259-3268.

24 Kapas I, Katko M, Harangi M, Paragh G, Balogh I, Koczi Z, Regelsberger G, Molnar MJ, Kovacs GG: Cerebrotendinous xanthomatosis with the c.379C $>\mathrm{T}$ (p.R127W) mutation in the CYP27Al gene associated with premature age-associated limbic tauopathy. Neuropathol Appl Neurobiol 2014;40:345350.

25 King A, Al-Sarraj S, Troakes C, Smith BN, Maekawa S, Iovino M, Spillantini MG, Shaw CE: Mixed tau, TDP-43 and p62 pathology in FTLD associated with a C9ORF72 repeat expansion and p.Ala239Thr MAPT (tau) variant. Acta Neuropathol 2013;125:303-310.

26 Gelpi E, van der Zee J, Turon Estrada A, Van Broeckhoven C, Sanchez-Valle R: TARDBP mutation p.Ile383Val associated with semantic dementia and complex proteinopathy. Neuropathol Appl Neurobiol 2014;40:225230.

27 Caillet-Boudin ML, Fernandez-Gomez FJ, Tran H, Dhaenens CM, Buee L, Sergeant N: Brain pathology in myotonic dystrophy: when tauopathy meets spliceopathy and rnaopathy. Front Mol Neurosci 2014;6:57.

28 Kiely AP, Asi YT, Kara E, Limousin P, Ling H, Lewis P, Proukakis C, Quinn N, Lees AJ, Hardy J, Revesz T, Houlden H, Holton JL: Alphasynucleinopathy associated with G51D SNCA mutation: a link between Parkinson's disease and multiple system atrophy? Acta Neuropathol 2013;125:753-769.

29 Distl R, Treiber-Held S, Albert F, Meske V, Harzer K, Ohm TG: Cholesterol storage and tau pathology in Niemann-Pick type C disease in the brain. J Pathol 2003;200:104-111.

30 Van de Warrenburg BP, Lammens M, Lucking $\mathrm{CB}$, Denefle P, Wesseling P, Booij J,
Praamstra P, Quinn N, Brice A, Horstink MW: Clinical and pathologic abnormalities in a family with parkinsonism and parkin gene mutations. Neurology 2001;56:555-557.

31 Bieniek KF, Murray ME, Rutherford NJ, Castanedes-Casey M, De Jesus-Hernandez M, Liesinger AM, Baker MC, Boylan KB, Rademakers R, Dickson DW: Tau pathology in frontotemporal lobar degeneration with C9ORF72 hexanucleotide repeat expansion. Acta Neuropathol 2013;125:289-302.

32 Holton JL, Lashley T, Ghiso J, Braendgaard H, Vidal R, Guerin CJ, Gibb G, Hanger DP, Rostagno A, Anderton BH, Strand C, Ayling H, Plant G, Frangione B, Bojsen-Moller M, Revesz T: Familial Danish dementia: a novel form of cerebral amyloidosis associated with deposition of both amyloid-Dan and amyloid-beta. J Neuropathol Exp Neurol 2002;61: 254-267.

33 Leverenz JB, Yu CE, Montine TJ, Steinbart E, Bekris LM, Zabetian C, Kwong LK, Lee VM, Schellenberg GD, Bird TD: A novel progranulin mutation associated with variable clinical presentation and tau, TDP43 and alpha-synuclein pathology. Brain 2007;130:1360-1374.

34 Jansen C, Parchi P, Capellari S, Strammiello R, Dopper EGP, van Swieten JC, Kamphorst W, Rozemuller AJM: A second case of Gerstmann-Straussler-Scheinker disease linked to the G131V mutation in the prion protein gene in a Dutch patient. J Neuropathol Exp Neurol 2011;70:698-702.

-35 Paisan-Ruiz C, Li A, Schneider SA, Holton JL, Johnson R, Kidd D, Chataway J, Bhatia KP, Lees AJ, Hardy J, Revesz T, Houlden H: Widespread Lewy body and tau accumulation in childhood and adult onset dystonia-parkinsonism cases with PLA2G6 mutations. Neurobiol Aging 2012;33:814-823. 